\title{
IN MEMORY OF \\ JAMEs E. Sublette (1928-2012)
}

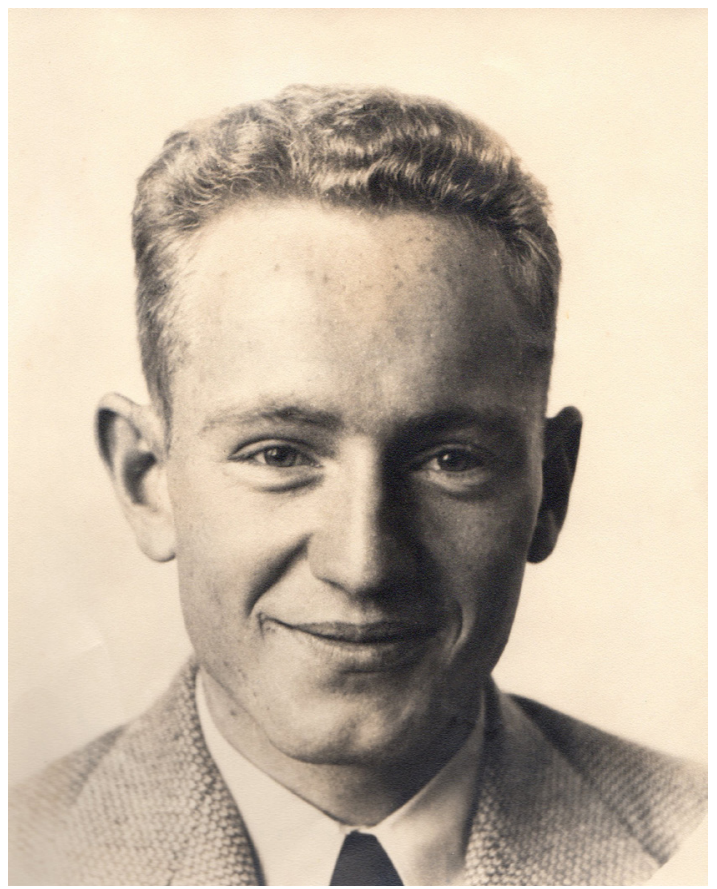

A young James E. Sublette, 1953. Photo: courtesy of the Sublette family.

James Edward Sublette was born in Oklahoma on January 19, 1928 to Samuel Hubbard Sublette and Pearl Mae Graves Sublette and raised in Arkansas, the $3^{\text {rd }}$ of 4 children. He was a descendent of Abraham Soblet, a Huguenot who came to this country in 1700 to escape religious persecution. At the age of 3 , Jim came down with polio and survived with limited use of his right arm, a disability that meant that he could not serve in the armed forces during World War II and allowed him instead to attend college. Jim went to elementary school in a one-room schoolhouse in Arkansas and graduated valedictorian of his high school at the age of 15 . Until he attended college at the University of Arkansas, he didn't have electricity or running water. In graduate school at the University of Oklahoma, he met his wife and lifelong scientific partner, Mary Frances Smith (1927-2007). Jim was always interested in zoology, especially fish, which led to the study of Chironomidae. He attained his $\mathrm{PhD}$ in entomology at the age of 23 and went on to be a world-renowned expert in his field, having identified, named, and described over 150 species of insects.

Jim was on the faculty of Eastern New Mexico University for most of his career, where for many years he served as Dean of the Graduate School. James and Mary were a productive team, working together tirelessly on studies of chironomid taxo- nomy as well as other groups. One of their definitive works (coauthored by Michael D. Hatch) was "The Fishes of New Mexico". Jim's children fondly remember dinner table conversations about Tanytarsus and family vacations which would center around water sources from which they collected larval specimens.

After his retirement from ENMU, Jim went on to be a faculty member at the University of Colorado in Pueblo for several additional years, after which he and Mary moved to Tucson, Arizona, where they spent a happy retirement, although Jim never actually stopped working on his taxonomic studies. Even after the death of Mary in 2007, Jim continued to work every evening on his big Zeiss microscope, practically to the very end of his life. In retirement he also took up artistic pursuits, creating biologically-inspired prints with his close friend, artist Gloria Isaak Morton.

Dr. James Edward Sublette was a renowned scientist who, together with Mary Frances, his wife of 57 years, made lasting contributions to the field of entomology. Moreover, he was a devoted husband, father, grandfather, and great-grandfather. He inspired numerous graduate students and was beloved by colleagues around the world. This brief

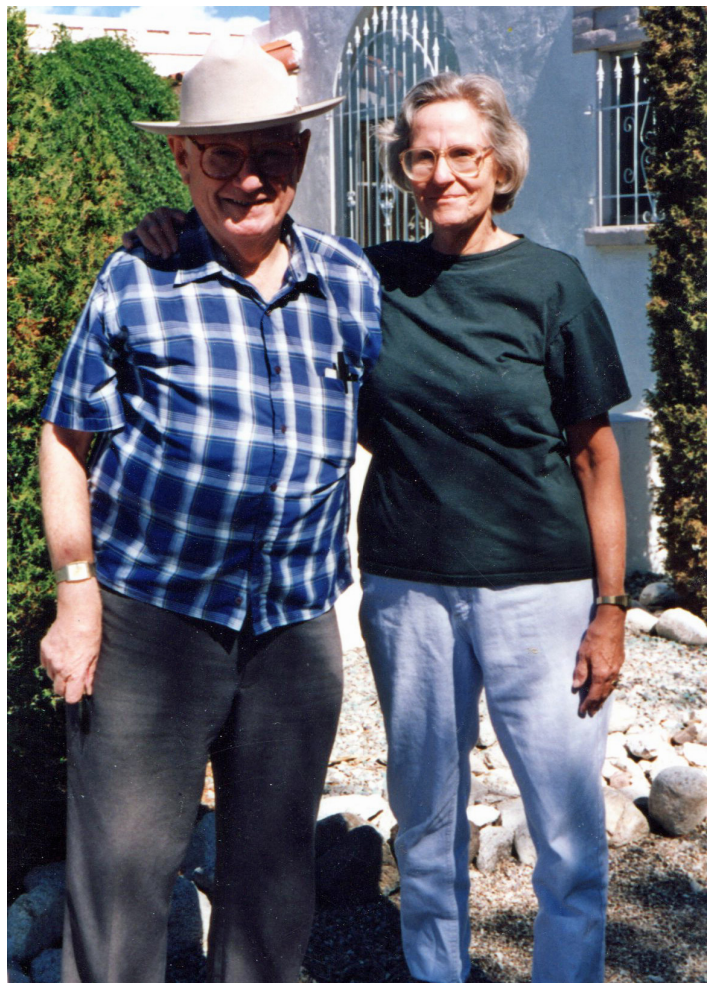

Jim and Mary outside their home in Tucson, 1994. Photo: courtesy of the Sublette family. 
narrative of his accomplishments, however, does not capture his greatness of spirit, his insatiable curiosity about the world around him, his gentle manner, his tremendous sense of humor, his love of languages, music, poetry, travel, good food, science fiction, and, well, life.

Jim died a peaceful death on December 15, 2012, survived by four married children, Ned, Elizabeth, Mark, and Amy; eight grandchildren, Sarah, Naomi, Rose Mary, James, Reuven, Charles, Yael, and Tori; and one great-grandson, Eli.

\section{The Sublette family}

\section{Jim Sublette the chironomidologist}

Jim published his first paper in the year I entered primary school (1955) and his last (in 2012) after I had retired. His works, and those co-authored by his wife Mary, have been with me throughout my career. By the time I started my $\mathrm{PhD}$ research in the early 70's, Jim's bibliography demonstrated how essential it was to understand the ecology of the species and systems in which the chironomids lived. It was Frieder Reiss, closer to me in age, who pointed out the importance of inclusion of the immature stages in our studies, pointing to Jim, Sam Roback and E.J. (Sepp) Fittkau from the previous generation as exemplifying the benefits of knowing the natural history. Of course, Frieder himself had come in to the field of chironomid systematics from a limnological ecological background too.

Jim's early papers ranged from what might be termed 'inventories', as in his studies of the benthos of Lake Texoma and an Ozark headwater stream, extending to catalogs of regional chironomid biotas (Alabama, California). These included descriptions of new life stages for already named species and description of new species. Jim understood the need for detailed study of nomenclature before naming new taxa, and to this end he studied the types of already described species across the USA. Not all ecologists turned taxonomists have so carefully checked not only the existing literature, but the type species. Thanks to Jim's model behaviour, North American chironomid workers had well-understood, carefully redescribed species on which to base their work.

The Sublettes did not decline the routine 'housekeeping' tasks of systematics such as the cataloging of regional biotas. Thus in $1965 \mathrm{Jim}$ and Mary produced the Chironomidae chapter for $A$ catalog of the Diptera of America north of Mexico, and 8 years later, contributed to the Catalogue of

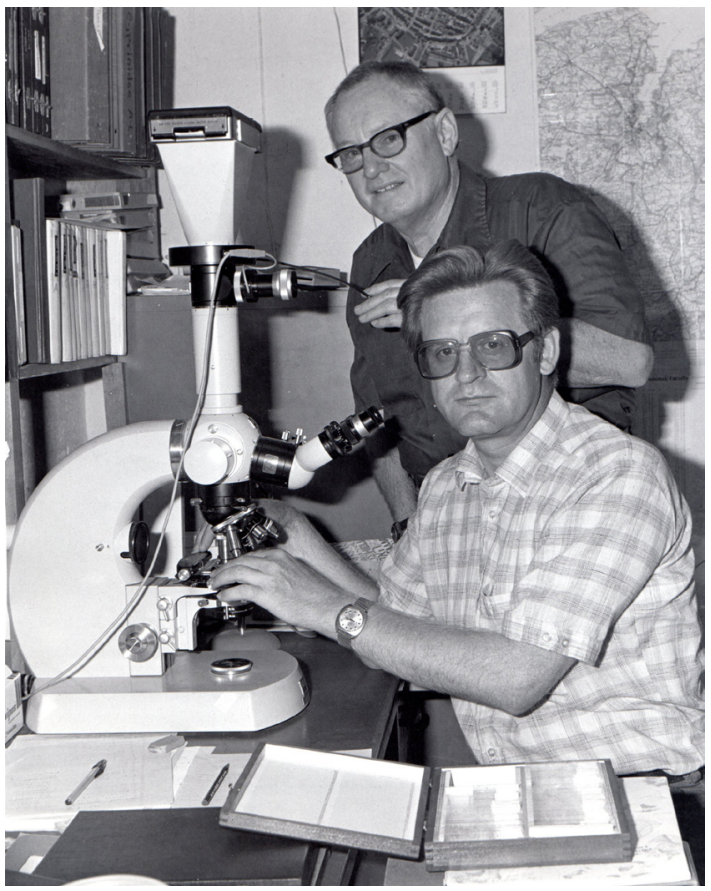

Jim Sublette and Friedrich Reiss, Portales, New Mexico, 1980. Photo: courtesy of Mary and Jim Sublette.

the Diptera of the Oriental Region (1973). To my mind they were unfortunate in the timing of these works, especially the North American work. Two schisms had not been reconciled at this time - the first concerned different nomenclatures that were applied on either side of the Atlantic, partially but not restricted to interpretation of Meigen's works and exacerbated by dilatory (in)action by the International Commission on Zoological Nomenclature. Henry Townes' brief flirtation with the Chironomidae was aligned with the interpretation that was eventually over-ruled - and this was followed largely by Jim and Mary in their catalog. A second issue was the reconciliation (or lack of) between the immature stages and adult-based classification. Despite Johannsen's work in the USA on the immature stages, and Jim's own strong understanding of the larvae and pupae, another gulf existed, which was really not reconciled until the multi-authored 'Holarctic keys' appeared in the 1980s. The two catalogs mentioned above were produced during this period of uncertainty concerning higher classification, and, to my mind, suffered accordingly. Never-the-less when in Ottawa with Don Oliver and Mary Dillon we brought the regional catalog into line with the newer generic concepts (published in1990); the Sublettes' species data was exceptionally thorough and accurate.

Taxonomically Jim's interests were broad, but with a special place for the genera Chironomus (often with Mary) and Tanytarsus, and he did not shirk from the extra-diverse Cricotopus or the little 
black orthoclads. Concerning Chironomus Jim and Mary worked closely with Wolfgang Wülker, Jon Martin and Malcolm Butler using a range of contemporary taxonomic tools including karyology and the then recently-developed scanning electron microscope to aid in understand this difficult, recently-radiating group. This interest extended right to the end of Jim's career with 3 of the last 5 papers he co-authored concerning the genus.

The studies of Chironomus exemplify Jim's eagerness to collaborate. Amongst other studies I see collaborations with W.W. (Bill) Wirth, Ole Sæther, Frieder Reiss and to a lesser extent Manabu Sasa, as important in extending the taxonomic and geographic range. The collaboration including a sabbatical in Bergen with Ole Sæther showed Jim's recognition of the narrower generic concepts applied well to the difficult Orthocladiinae that Jim had been rearing for years. His collections were immense and extraordinarily well curated as visitors to the post-retirement Sublette lab would find. Even the illness and subsequent death of Mary did not alter the scientific and personal hospitality shown to visiting chironomid systematists, as colleagues attest below. Jim surely was a mentor, friend and colleague to so many in the chironomid community.

An interest of Jim's known to many outside the midges was native fishes - and his most cited contribution to science is the book he wrote with Mary and M.D. Hatch, 'The Fishes of New Mexico'. Less known was his interest into chironomid allergy in Japan - we met there in the late 1980s thanks to the beneficence of Manabu Sasa. I'm not sure we helped allergy sufferers but we spent happy days discussing midges, chironomidologists, Japanese customs; and his beloved south-western USA all very charitably.

Jim prepared for his death in a very systematic manner - while at University of California, Davis, Jim sent me back several boxes of slides, both returned loans and donations of Californian midges. In 2012 he sent some 87,000 prepared slides of Chironomidae to the University of Minnesota, including many recognised, but undescribed, species. He chose here to house his collection because of his respect for Edwin Cook, the director of the University of Minnesota Insect Collection, who helped build it into one of the most important insect collections in North America. All of the slides from this donation have been scanned and digitized and are becoming available at www.insectcollection.org (requires password and login 'guest').

Peter S. Cranston, Canberra

\section{Memories of Jim}

I was greatly saddened to learn of the death of Jim Sublette, one of the kindest people I have ever met.

Perhaps some of the younger workers today do not realize the influence Jim had on North American chironomid work. During the 60's and 70's Jim went through the collections at the major museums in North America and redescribed many of the type specimens of species previously described by earlier workers. Some of these older descriptions were quite short and/or lacked useful illustrations of genitalia, etc., a problem that Jim's papers helped resolve. Jim and his wife Mary were pioneers

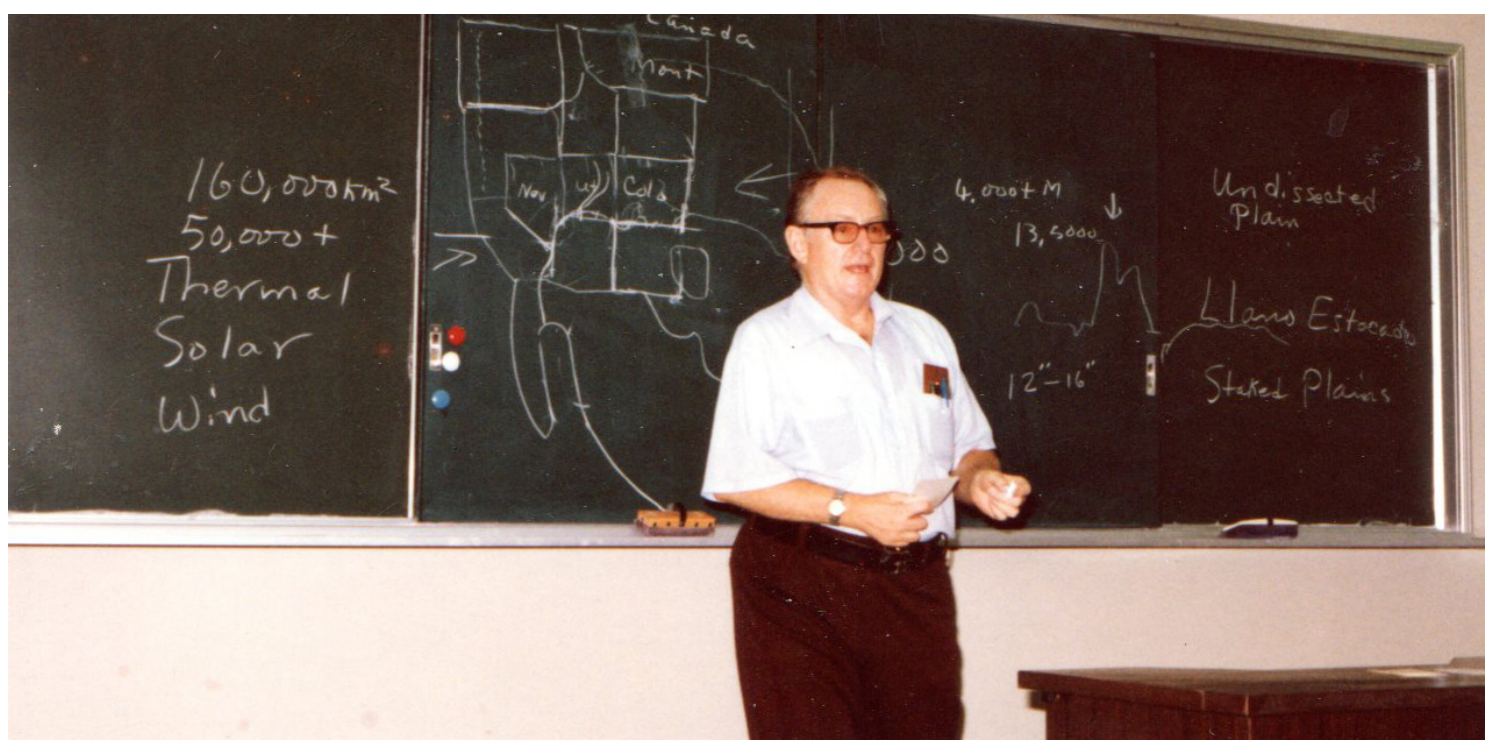

Jim Sublette lecturing at Eastern New Mexico University, c. 1975. Photo: courtesy of the Sublette family. 
in the study of that vexing tribe, the Tanytarsini. University duties, other avenues ("The Fishes of New Mexico", etc.) and health concerns took much of their time, but many of these Tanytarsus species were finally described in a collaborative work with Torbjørn Ekrem in 2003. Many more species, in Tanytarsus and other tanytarsine genera, remain to be described; in several collections one can find specimens with labels that bear Jim and Mary's new names but these names are not currently available.

I was fortunate to first meet Jim in June of 1980, at his lab in Portales, NM. I was there to go through his collection for specimens of Dicrotendipes for my revision of the Nearctic members of that genus. Jim was his usual kind and generous self.

I next saw Jim and Mary at the 8th International Symposium on Chironomidae at Jacksonville, FL, in 1982 (that's me, when I still had hair on the top of the my head, standing next to Mary and Jim in the group photo).

My last visit with Jim and Mary was in 1995, at their wonderful house in Tucson, AZ. I had brought a large number of unidentified/undescribed Tanytarsini from the Southeastern US. We spent several days going over them - and enjoying some delicious meals! My wife Linda had a great time playing with some of the grandkids. Because my brother lived just a few miles down the road, I stayed with him and missed out on staying at Jim and Mary's nifty pool house!

Jim was the master of Nearctic Chironomus, and was always ready to help with identifications of this difficult genus - actually, Jim was ALWAYS ready to help with any problem! Jim was atypical for some of his generation, for he kept up on computer-related matters and was always easy to contact through email. He also took numerous SEMs of Chironomidae. I greatly treasure the print of the SEM he gave me of the gaping maw of a Dicrotendipes crypticus larva.

He will be sorely missed ...

J.H. Epler, Crawfordville, FL

In July 1961 I took a position at the University of California, Riverside, CA, USA. My contract was for a four year period, and I was to work under Dr. Lauren D. Anderson on studies of chironomid flies with the intent to control their numbers in various settings. Insecticides and biological control methods were investigated for their possible application.
Initially the taxonomy of our fly subjects did not play a major role in this project; I was informed that there were about five species involved. When, after some time, I pointed out that I had recognized at least thirty different species in the samples, I was offered the opportunity to be the "taxonomist" in our group. At that time only a handful of authoritatively identified specimens from California were available to me, so for my identifications I had to resort to what little pertinent literature was at hand. Since I was a novice at preparing and identifying specimens, it seemed wise to bring them to the attention of a more experienced authority who I hoped would be willing to evaluate my attempts at identification. That scientist turned out to be Dr. James Edward Sublette. Needless to say, I was de-

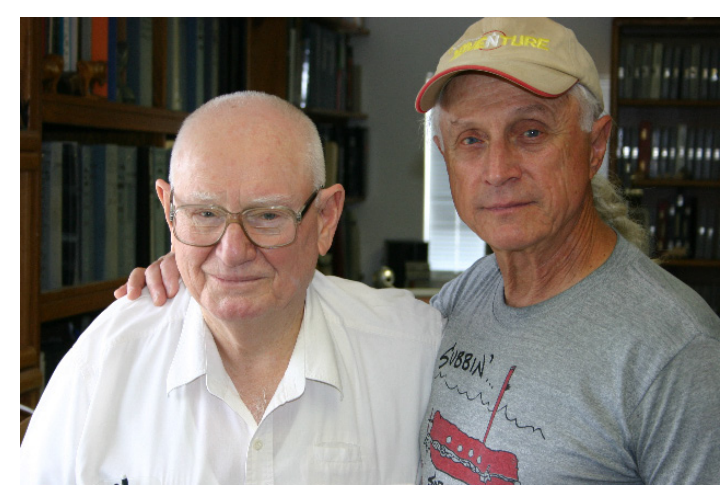

Jim Sublette \& Saul Frommer, 2006. Photo: Saul Frommer.

lighted to learn from him that I was succeeding in this endeavor.

Not long after our initial correspondence I encouraged Dr. Sublette to visit UCR, and this he did, accompanied by his wife, Mary. As some of you may know, Mary was also a close professional associate of Jim's, the two sharing the work necessary for any project Jim was involved in. We decided to meet at a restaurant in Riverside, and I will never forget that on this very first meeting with the Sublettes I was offered for study all of the material they possessed in the subfamily Orthocladiinae. Quite many taxonomists covet the material in their collections so much that it is not always obtainable for loan, yet this was not the case with the Sublettes, who were more interested in moving the science forward than in building and guarding their personal collection. Nevertheless I had to decline their offer, not only because I already had enough work at hand, but more because I felt too much like a fledgling researcher to contemplate such a task.

On one of Jim's early visits to UCR I introduced him to scanning electron microphotography. I was not using the technique myself, but felt that he 
would be interested in it for his research. A session with UCR's SEM technician was made, and it took no more than that initial trial to convince Jim of the technique's value. The rest is history, Jim took the ball and ran with it. At the time he was a dean in the zoology department of Eastern New Mexico University in Portales, and he managed to arrange for monthly scanning sessions at Los Alamos National Laboratory, New Mexico, where he could examine his Mücken (Jim really enjoyed using what he referred to as Milwaukee Plattdeutsch, a derivative of the Low German language). The work at Los Alamos enabled him to obtain fine illustrations for his publications; I recall in particular figures of larval heads and mouthparts.

From the time the Sublettes spent in Portales through the years they lived in retirement in various places, my wife and I would take short vacations to visit them. For me this meant visiting the Chironomid Oracle of the West. I could study slides and learn of literature that otherwise might not have come to my attention, and of course I could make and take copies. When my wife and I were involved in international folk dancing, Jim arranged for us to conduct a teaching session for interested students at his university. On another occasion he asked whether I would like to sort the university's fly collection, which was used for teaching entomology. This job brought to light an undescribed male belonging to a rare genus of Acroceridae that I could then trade for four other species to Dr. Evert I. Schlinger, a world authority on that fly family working at UCR at the time.

Over the years my wife and I came to cherish the Sublettes as part of our extended family, and this relationship lasted to the ends of their lives. Their passing has left immense holes in our hearts. They will be remembered always for their gracious sharing of knowledge and good humor. Our friendship lasted for more than 50 years and lives on in the form of memories of good times shared.

Saul I. Frommer, Murrieta, CA

The great senior among the world's chironomidologists, the witness and the participant of the early chironomid research ["...I had the pleasure of meeting Lenz in Vienna in 1959..." (from Jim's letter, July 2011)]. My chance of meeting Jim, sadly, passed, despite repeated invitations to Tucson. Jim was cheerful and gentle, always willing to encourage and to advise. He remains the perpetual inspiration.

Wojciech Giłka, Gdansk
I first made contact with Jim and Mary Sublette in 1966 while I was a NRC Post-doctoral fellow at the Entomology Research Institute (now Biosystematics Research Institute) in Ottawa, Canada. We arranged that my family and I should travel down to Urbana, Illinois, where Jim and Mary were studying the collection in the Illinois Natural History Survey, in August. From this meeting began a collaboration that continued for the next 47 years, leading to about 16 publications, often also involving Wolfgang Wülker.

Jim found funding for me to work with him for three months in Portales, N.M., when I finished my post-doc at Ottawa. As we prepared to leave Ottawa by car and travel the 3000 miles to Portales, a message came from Jim - could I detour via Prince Alfred National Park in Saskatchewan and collect specimens of Chironomus rempelii. So off we went (but only obtained adults) - a 3000-mile detour to our 3000-mile trip, but which enabled us to see parts of North America we would not otherwise have seen.

At this time Jim was Dean of Graduate Studies at Eastern New Mexico University and I was impressed at his ability to divide his time between administration, research and family - whichever he was doing it had his full attention. When he was in the lab he was always on the move, and always at a fast pace - due to his "high speed rear-end". I think one of the things Jim really regretted about the return of his polio, was the loss of his mobility.

While in Portales I learned much about chironomids from Jim and Mary often from a very different perspective from what I had learned from Don Oliver in Ottawa. However, it is to these three that I owe my knowledge of systematics, as all my training had been as a geneticist.

I visited Jim and Mary three more times in Portales, during which time I met other chironomidologists who came to visit Jim - Sepp Fittkau, Wolfgang Wülker, Gail Grodhaus, amongst others, but also gained introductions to many others through their contacts with Jim. Subsequently I visited in Colorado and Tucson, while we tried to distinguish the 100 or so species of Chironomus, particularly the $C$. decorus complex, now recorded from North America. Jim had very definite views about taxonomic nomenclature, which didn't always coincide with those of other workers. One of these was that pupae had exuviae, regardless of whether it was singular or plural. His nit-picking ensured a high standard for our publications. 
When we visited the Sublettes we were always treated as family, being loaned cars, and sharing Thanksgiving and Christmas dinners with their family. It was a source of sorrow that Jim was not able to visit us in Australia so we could return the hospitality.

We continued to collaborate right up until the time of Jim's stroke - I had emailed him with a query about the day before it happened, although it was some time before I learned why I received no reply.

Jim's death is a great loss to the chironomid community, and for me the loss of a very good friend and valued colleague.

\section{Jon Martin, Melbourne}

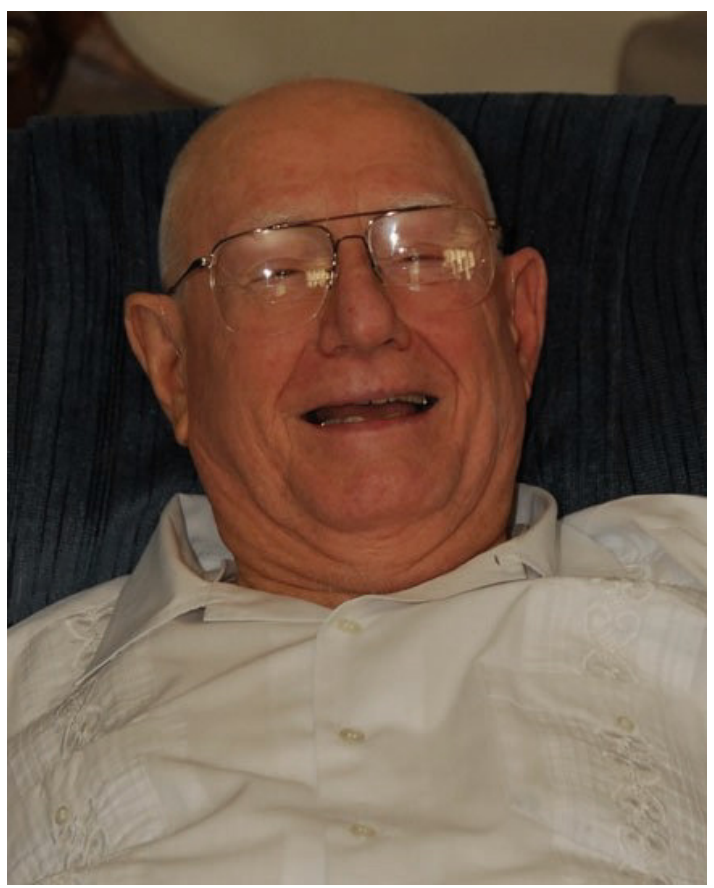

Jim Sublette at his home in Scottsdale, Arizona, 2010 Photo: Jay Steeby.

The only time I met Jim and Mary in person was when I visited with them in Tucson for a week while working on southern California midges in the early 1990s. The purpose of our meeting was to exchange chironomid information and material, but the Sublettes were not the kind of people to limit encounters to that level, not even with someone they barely knew from just a little professional communication. It seemed the most natural to them to accommodate me in their home, let me use their outdoor pool (Arizona during the peak of summer!), chauffeur me to and from a repair shop when my car needed two days' worth of fixing, and to spend hours with me every day beyond those they could allot to scientific studies. Jim did all the kitchen work (I think this wasn't only because Mary was a bit unwell that week), and his cooking was memorably delicious (unlike that of many without any physical handicap). In the evenings, when they had time we would share pleasant stories about colleagues and places we knew, and some I didn't know. That week with Jim and Mary will always rank among the best of times I've spent in the company of colleagues.

Within the confines of chironomid science, the Sublette \& Sublette team have earned our eternal reverence for their contributions to the field. Especially impressive here is their early and enduring prudence and readiness to produce resources useful not only to them, and to engage in the building of a research community in the best sense of this term.

Their legacy stands to remind us that our opportunity to walk and work this Earth among others should not be wasted on reaping what can be taken, but calls for us to join in the service of sowing, and providing for plates well beyond our own. So, here's to Jim for going so long and strong, and always with a smile for the giving, rather than giving in to fate or pain.

Martin Spies, München

We were fortunate to visit Jim and Mary at their house in Tucson at two occasions in May 2001 and February 2006. The hospitality was fantastic and we truly enjoyed our stays in their "pool house". Coming from the relatively cold and wet north, the heat and dryness of the Arizona desert was fascinating. - As was dipping in an outdoor pool that probably held more than $35^{\circ} \mathrm{C}$ to "cool off" in the evening.

Jim was fond of cooking and trying new food, and we greatly enjoyed preparing and eating homecooked meals together with him, Mary and the Steeby family.

Despite his handicap, Jim was hard working and still going strong when we met. While in Tucson, we were impressed by his immense knowledge of the Tanytarsus/Micropsectra species we worked on and how much he remembered of each and every species, even if he had not worked on them for many years.

Jim and Mary's draft review of the Tanytarsini of the new world has been and still is a great resource for those of us studying this group of midges. Also, the Sublette collection is a fantastic resource for research on North American chironomids. We 


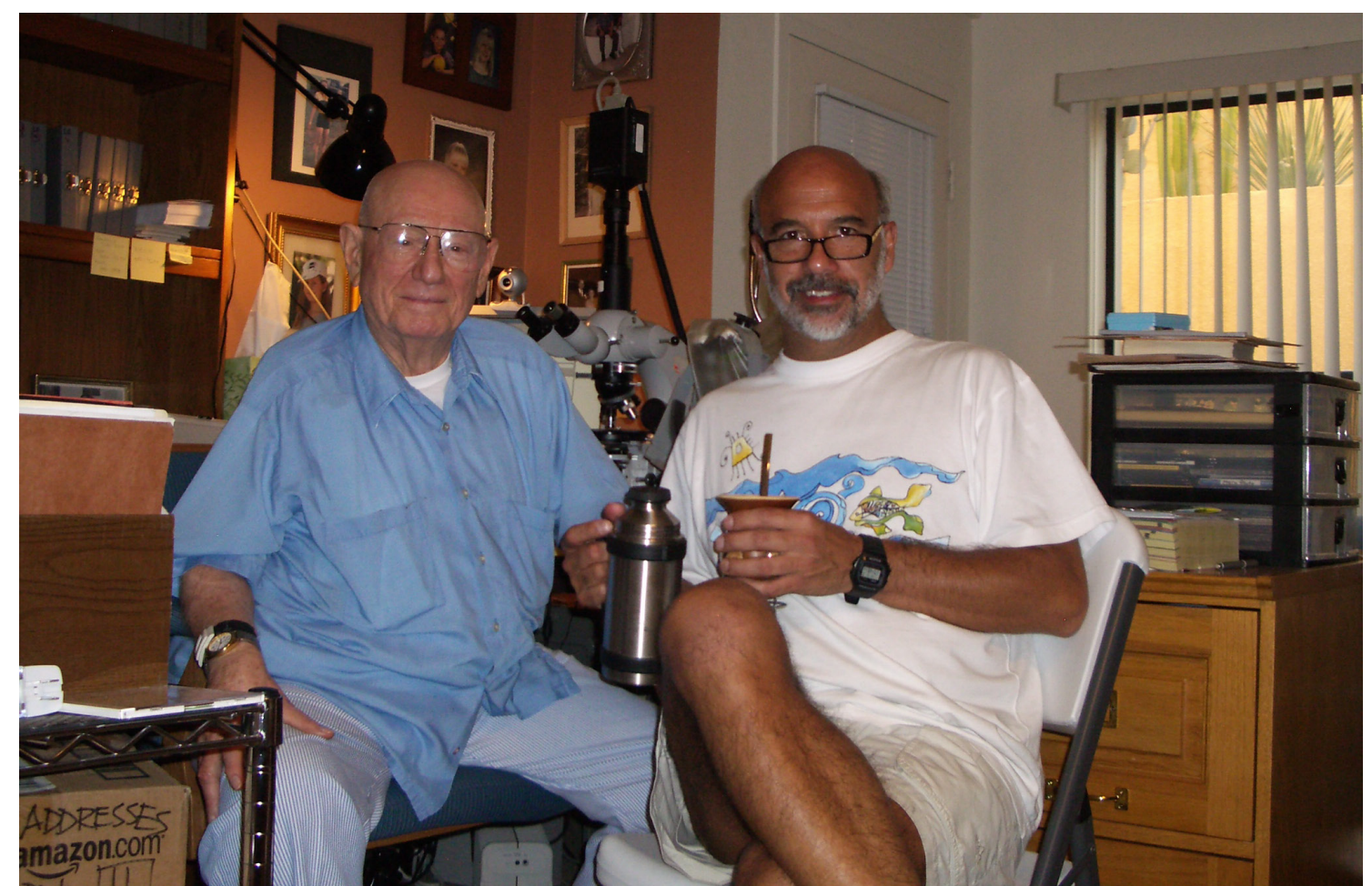

Jim and Diego Suárez at Jim’s home in 2010. Photo: Diego Añón Suárez.

were overwhelmed when we first visited Jim's lab to see all the boxes with slides and pinned specimens that filled the multiple rooms in their Tucson house. - And, maybe even more so when we were offered a long-term loan of the majority of the Tanytarsini specimens after our first visit. At our second visit we prepared several dozens of boxes of Tanytarsini slides and brought them with us on the return flight to Trondheim. They almost got stuck at the Phoenix airport, though, as an overambitious airline staff member claimed that dead chironomids on microscope slides had to constitute a security threat or illegal export. Not even the assurance from her supervisor seemed convincing, but our big box of midges finally was accepted as check-in luggage.

We think back at our visits in Tucson with joy and regret that we did not have the chance to meet with Jim the last couple of years. He really wanted to attend the 18th International Symposium on Chironomidae in Trondheim in 2011, but travel just became too difficult. We will always remember Jim as a good friend and colleague. He might not be with us anymore, but his legacy will live through his publications, collection and our good memories.

Elisabeth Stur \& Torbjørn Ekrem, Trondheim
I was lucky to have the opportunity to meet Jim in 1999 after meeting of North American Benthological Society in Duluth. I planned to visit an Argentine friend in Tucson and John Epler recommended me to visit Jim. Since then, we had a pretty close friendship despite the distance, and I returned to Tucson during 2001 to work with him. It was Jim who taught me to process and identify exuviae that I collected in Bariloche. At that time I had the opportunity to meet his family with whom I shared very nice moments. Besides from working, I cooked some Argentinean dishes for them. At the same time I met and shared good times with Torbjørn and Elisabeth, who appreciate it. I returned to Tucson in 2010, when Mary his wife was no longer with us, and we were working together on the description of a new genus from alpine lakes of Patagonia. I accepted Jim's invitation to stay with him for a couple of weeks, sharing work and talking about life and also sharing food and "mate". Besides being a thorough professional from whom I learned a lot, Jim was for me a very warm human being, affectionate, and very interested in culture, beyond science. During my working hours with him, we share many conversations about the customs of our respective countries, different kinds of food, places of the world, etc. etc. In fact during my stays at his home, he liked and enjoyed several dishes from Argentina that I cooked.

Despite the newness of our contact and the short 
time we shared, we maintained frequent contact by email or Skype. I always felt Jim to be a friend and I miss him. This brief reminiscence is for Jim, the Great Bear White (Gran Oso Blanco) as he called himself. Thanks for all, dear Jim.

Diego Añón Suárez, Bariloche

I was Jim Sublette's student while he taught at Colorado State University, Pueblo (formerly University of Southern Colorado) a primarily undergraduate institution. Students at CSU, Pueblo had little experience seeing research in action. Jim wove anecdotes and lessons on research into most of his lectures, so that students came to understand

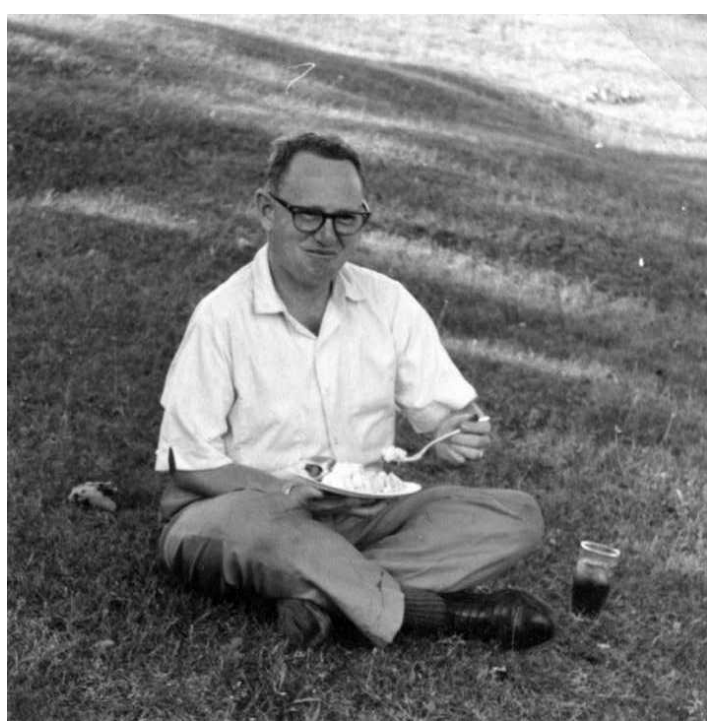

Jim near the house of his brother, Shafer Lake, Indiana, 1964. Photo: Wolfgang Wülker.

the nature of research. I am so glad that I had Jim as a professor, although I never took an Entomology class from him. Instead I took Ichthyology and found him to be an engaging and fascinating lecturer, to the point that I hung on his every word. He also became my role model for combining teaching and research. However, it was not until I started teaching at a small undergraduate institution that I came to understand how unique he was in being such an accomplished researcher while maintaining a heavy teaching load. Professors at small institutions often do all of their lecture and laboratory preparation and grading without the assistance of graduate student teaching assistants. They do most of their research without fellow researchers or graduate research assistants, although Jim was very fortunate to have a collaborator in his wife, Mary. What I have come to find is that he must have done his research on top of his full time job teaching. His valuable body of work was con- ducted in the corners of his days, his evenings, and his weekends. His legacy stands as an inspiration to those of us who continue to study Chironomidae in the crooks and crannies of our days.

Barbara Hayford, Wayne NE

\section{Dear Jim!}

I remember your slogan "Better to be a big fish in a small pond than to be a small fish in a big pond". Indeed, you were a big fish although not in a small pond! We have known each other since 1959 and remained in contact through email until middle 2012 - a long time. You reported in your emails from "Tucson Sunday" or "Tucson Thursday", I was so happy to get these notes. Also, in your last year you described together with Diego Suárez the genus Wuelkerella from a cold lake in Argentina - big honour and proof of our long friendship. Through the years we had many meetings in USA, Norway and Germany. In 1964 you sponsored an unforgettable trip for family Wülker through the USA, from Indiana (see photo) west to the Pacific coast and back east to Portales, covering Niagara Falls, Yellowstone and Grand Canyon. Big impressions for me, my two sons aged 7 and 8 and their mother. Many chironomids were collected, which Mary brought on slides in many boxes!

You and dear Mary were a highlight in our life. I remember Mary said that we are like twins, which we indeed were - at least in a scientific sense. We will miss you both! You can look back on a voluminous work, which your daughter Amy described so completely. Fare well! Yours, Wolfgang.

Wolfgang Wülker, Freiburg

\section{Bibliography}

Sublette, J.E. 1955. The physico-chemical and biological features of Lake Texoma (Denison Reservoir), Oklahoma and Texas: A preliminary study. - Texas Journal of Science 7: 164-182.

Sublette, J.E. 1956. Seasonal changes in bottom fauna of an Ozark headwater stream (Clear Creek, Washington County, Arkansas). - The Southwestern Naturalist 1: 148-156.

Sublette, J.E. 1957. The immature stages and female of Polypedilum (Polypedilum) obtusum Townes (Tendipedidae: Diptera). - Entomological News 68: 37-40.

Sublette, J.E. 1957. The ecology of the macroscopic bottom fauna in Lake Texoma (Denison 
Reservoir), Oklahoma and Texas. - American Midland Naturalist 57: 371-402.

Sublette, J.E. and Dendy, J.S. 1957. The immature stages of Tendipes (Tendipes) crassicaudatus Malloch (Tendipedidae: Diptera) with notes on life history and ecology. - Journal of the Kansas Entomological Society 30: 121-124.

Dendy, J.S. and Sublette, J.E. 1959. The Chironomidae (=Tendipedidae: Diptera) of Alabama with descriptions of six new species. - Annals of the Entomological Society of America 52: 506-519.

Sublette, J.E. and Dendy, J.S. 1959. Plastic materials for simplified tent and funnel traps. - The Southwestern Naturalist 3: 220-223.

Sublette, J.E. 1960. Chironomid midges of California. I. Chironominae, exclusive of Tanytarsini (=Calopsectrini). - Proceedings of The United States National Museum 112: 197-226.

Sublette, J.E. 1964. Chironomid midges of California. II. Tanypodinae, Podonominae, and Diamesinae. - Proceedings of The United States National Museum 115: 85-136.

Sublette, J.E. 1964. Chironomidae (Diptera) of Louisiana I. Systematics and immature stages of some lentic chironomids of west-central Louisiana. - Tulane Studies in Zoology 11: 109-150.

Buckley, B.R., and Sublette, J.E. 1964. Chironomidae (Diptera) of Louisiana II. The limnology of the upper part of Cane River Lake, Natchitoches Parish, Louisiana, with particular reference to the emergence of Chironomidae. $-T u$ lane Studies in Zoology 11: 151-166.

Sublette, J.E. and Sublette, M.S. 1965. Family Chironomidae (Tendipedidae). In: Sabrosky, C.W., Wirth, W.W., Foote, R.H., Coulson, J.R. (Eds.) A catalog of the Diptera of America north of Mexico. United States Department of Agriculture, Agriculture Handbook No. 276, pp 142-181.

Sublette, J.E. 1966. Type specimens of Chironomidae (Diptera) in the American Museum of Natural History. - Journal of the Kansas Entomological Society 39: 1-32.

Sublette, J.E. 1966. Type specimens of Chironomidae (Diptera) in the U.S. National Museum. - Journal of the Kansas Entomological Society 39: 580-607.

Sublette, J.E. 1967. Type specimens of Chironomidae (Diptera) in the Canadian National Collections, Ottawa. - Journal of the Kansas Entomological Society 40: 290-331.
Sublette, J.E. 1967. Type specimens of Chironomidae (Diptera) in the Cornell University Collection. - Journal of the Kansas Entomological Society 40: 477-564.

Sublette, J.E. and Sublette, M.S. 1967. The limnology of Playa Lakes on the Llano Estacado, New Mexico and Texas. - The Southwestern Naturalist 12: 369-406.

Sublette, J.E., Sublette, M.S., Beck, W., Beck, E. and Roback, S. 1968. Chironomid investigations in the U.S.A. - Chironomus 1: 22-24.

Wülker, W.F., Sublette, J.E. and Martin, J. 1968. Zur Cytotaxionomie [sic!] nordamerikanischer Chironomus-Arten. - Annales Zoologici Fennici 5: 155-158.

Sublette, J.E. 1969. Aquatic insects of the Rita Blanca Lake deposits. In: Anderson, R.Y., Kirkland, D.W. (Eds.) Paleoecology of an early Pleistocene lake on the high plains of Texas. Geological Society of America Memoirs 113: 117-122.

Sublette, J.E. 1970 Type specimens of Chironomidae (Diptera) in the Illinois Natural History Survey Collection, Urbana. - Journal of the Kansas Entomological Society 43: 44-95.

Wirth, W.W. and Sublette, J.E. 1970. A review of the Podonominae of North America with description of three new species of Trichotanypus (Diptera: Chironomidae). -Journal of the Kansas Entomological Society 43: 335-354.

Frommer, S.I. and Sublette, J.E. 1971. The Chironomidae (Diptera) of the Philip L. Boyd Deep Canyon Desert Research Center, Riverside Co., California. - Canadian Entomologist 103: 414-423.

Mason Jr, W.J. and Sublette, J.E. 1971. Collecting Ohio River Basin Chironomidae (Diptera) with a floating sticky trap. - Canadian Entomologist 103: 397-404.

Sublette, J.E. and Sublette, M.S. 1971. The Orthocladiinae (Chironomidae, Dipt.) of California. I. The Cricotopus infuscatus group. - Entomological News 82: 85-102.

Wülker, W.F., Sublette, J.E., Sublette, M.F. and Martin, J. 1971. A review of the genus Chironomus (Diptera, Chironomidae). I. The staegeri group. - Studies of Natural Sciences (Portales, New Mexico) 1(1): 1-89.

Martin, J. and Sublette, J.E. 1972. A review of the genus Chironomus (Diptera, Chironomidae). III. Chironomus yoshimatsui new species from 
Japan. - Studies of Natural Sciences (Portales, New Mexico) 1(3): 1-59.

Sublette, J.E. and Wirth, W.W. 1972. New genera and species of West Indian Chironomidae (Diptera). - Florida Entomologist 55: 1-17.

Sublette, J.E. and Sublette, M.S. 1973. The morphology of Glyptotendipes barbipes (Staeger) (Diptera, Chironomidae). - Studies of Natural Sciences (Portales, New Mexico) 1(6): 1-81.

Sublette, J.E. and Sublette, M.S. 1973. Family Chironomidae. In: Delfinado, M., Hardy, E.D. (Eds) Catalogue of the Diptera of the Oriental Region. Part 1. University Press of Hawaii, Honolulu, pp. 289-422.

Martin, J., Wülker, W.F. and Sublette, J.E. 1974. Evolutionary cytology of the genus Chironomus Meigen (Diptera: Chironomidae). - Studies of Natural Sciences (Portales, New Mexico) 1(12): 1-12.

Sublette, J.E. and Sublette, M.S. 1974. A review of the genus Chironomus (Diptera: Chironomidae). V. The maturus-complex. - Studies of Natural Sciences (Portales, New Mexico) 1(8): $1-41$.

Sublette, J.E. and Sublette, M.S. 1974. A review of the genus Chironomus (Diptera, Chironomidae). VI. The morphology of Chironomus stigmaterus Say. Studies of Natural Sciences (Portales, New Mexico) 1(10): 1-65.

Atchley, W.R., Sublette, J.E. and Sublette, M. 1979. Part I. Distribution of Chironomidae in relation to water quality parameters at selected STORET sites in New Mexico. In Sublette, J.E. (Ed.) Utilization of Chironomidae (Diptera) as a water quality indicator group in New Mexico. New Mexico Energy Institute / Technical Completion Report 32, pp. 1-52.

Martin, J., Sublette, J.E. and Sublette, M. 1979. Part III. Karyosystematics of selected Chironomidae of New Mexico. In Sublette, J.E. (Ed.) Utilization of Chironomidae (Diptera) as a water quality indicator group in New Mexico. New Mexico Energy Institute / Technical Completion Report 32, pp. 129-133.

Sublette, J.E. 1979. Scanning electron microscopy as a tool in taxonomy and phylogeny of the Chironomidae. In: Sæther, O.A. (Ed.), Recent developments in chironomid studies (Diptera: Chironomidae). - Entomologica scandinavica Supplement 10: 47-65.

Sublette, J.E. 1979. Utilization of Chironomidae
(Diptera) as a water quality indicator group in New Mexico. New Mexico Energy Institute / Technical Completion Report 32. New Mexico State University, Pueblo; 133+[16] pp.

Sublette, J.E. and Sublette, M.S. 1979. Part II. A synopsis of the Chironomidae of New Mexico. In Sublette, J.E. (Ed.) Utilization of Chironomidae (Diptera) as a water quality indicator group in New Mexico. New Mexico Energy Institute / Technical Completion Report 32, pp. 53-128.

Sasa, M. and Sublette, J.E. 1980. Synonymy, distribution, and morphological notes on Polypedilum (s.s.) nubifer (Skuse) (Diptera: Chironomidae). - Japanese Journal of Sanitary Zoology 31: 93-102.

Sublette, J. E. and Martin, J. 1980. Yama tahitiensis n. gen., n. sp. from Tahiti (Diptera: Chironomidae). - The Pan-Pacific Entomologist 56: 221-237.

Sublette, J.E. and Wirth, W.W. 1980. The Chironomidae and Ceratopogonidae (Diptera) of New Zealand's subantarctic islands. - New Zealand Journal of Zoology 7: 299-378.

Sæther, O.A. and Sublette, J.E. 1983. A review of the genera Doithrix. n. gen., Georthocladius Strenzke, Parachaetocladius Wülker and Pseudorthocladius Goetghebuer (Diptera: Chironomidae, Orthocladiinae). - Entomologica scandinavica Supplement 20: 1-100.

Sublette, J.E. and Sublette, M.S. 1983. Asheum, a replacement name in Chironomidae (Diptera). - Entomological News 94: 34.

Sæther, O.A., Sublette, J.E. and Willassen, E. 1984. Chironomidae (Diptera) from the 2nd Fram Expedition (1898-1902) to Arctic North America described by J. J. Kieffer. - Entomologica scandinavica 15: 249-275.

Reiss, F. and Sublette, J.E. 1986. Beardius new genus with notes on additional Pan-American taxa (Diptera, Chironomidae). - Spixiana Supplement 11: 179-193.

Cowley, D.E. and Sublette, J.E. 1987. Distribution of fishes in the Black River Drainage, Eddy County, New Mexico. - The Southwestern Naturalist 32: 213-221.

Cowley, D.E. and Sublette, J.E. 1987. Food habits of Moxostoma congestum and Cycleptus elongatus (Catostomidae: Cypriniformes) in Black River, Eddy County, New Mexico. - The Southwestern Naturalist 32: 411-413. 
Herrmann, S.J., Sublette, J.E. and Sublette, M.S. 1987. Midwinter emergence of Diamesa leona Roback in the upper Arkansas River, Colorado, with notes on other diamesines (Diptera: Chironomidae). - Entomologica scandinavica Supplement 29: 309-322.

Sublette, J.E. and Sublette, M.S. 1987. Microtrichial color determinants in Cricotopus (Diptera: Chironomidae). - Entomologica scandinavica Supplement 29: 87-89.

Sublette, J.E. and Sublette, M.S. 1988. An overview of the potential for Chironomidae (Diptera) as a worldwide source for potent allergens In: Miyamoto, T. (Ed.) International Symposium on Mite and Midge Allergy. Special Report of Ministry of Education, Science and Culture, University of Tokyo, Japan, pp. 190-231.

Sublette, M.S., Sublette, J.E. and Ferrington, L.C. Jr. 1989. Gail Grodhaus: March 21, 1928-December 23, 1987. - Journal of the Kansas Entomological Society 62: 294-296.

Wülker, W.F., Sublette, J.E., Morath, E. and Martin, J. 1989. Chironomus columbiensis sp. n. in South America and C. anonymus Williston in North America - closely related species. - Studies on Neotropical Fauna and Environment 24: 121-136.

Sublette, J.E. and Mulla, M.S. 1991. Goeldichironomus amazonicus (Diptera: Chironomidae), a potentially pestiferous midge recently discovered in California. - Entomological News 102: 47-49.

Wülker, W.F., Sublette, J.E. and Martin, J. 1991. Chironomus utahensis Malloch and Chironomus harpi new species and their karyosystematic relationships to other species of the decorus-group of Chironomus. - Spixiana 14: 71-94.

Chaudhuri, P.K., Das, S.K. and Sublette, J.E. 1992. Indian species of genus Chironomus Meigen (Diptera: Chironomidae). - Zoologische Jahrbücher, Abteilung für Systematik, Ökologie und Geographie der Tiere 119: 1-51.

Sublette, J.E. and Sasa, M. 1994. Chironomidae collected in onchocerciasis endemic areas of Guatemala (Insecta, Diptera). - Spixiana Supplement 20: 1-60.

Hayford, B.L., Sublette, J.E. and Herrmann, S.J. 1995. Distribution of chironomids (Diptera: Chironomidae) and ceratopogonids (Diptera: Ceratopogonidae) along a Colorado thermal spring effluent. In: Ferrington, L.C.Jr. (Ed.) Bi- odiversity of aquatic insects and other invertebrates in springs. Special Publication. Journal of the Kansas Entomological Society, supplement 68(2): 77-92.

Sublette, J.E. and Martin, J. 1995. Morphological variation in secondary sexual characteristics of gynandromorphic Chironomus (Camptochironomus) tentans Fabricius (Diptera, Chironomidae). In: Cranston, P.S. (Ed.) Chironomids: from genes to ecosystems. Proc. 12th International Symposium on Chironomidae, Canberra, January 23-26, 1994. CSIRO Australia, East Melbourne, pp. 343-353.

Sublette, J.E., Stevens, L.E. and Shannon, J.P. 1998. Chironomidae (Diptera) of the Colorado River, Grand Canyon, Arizona, USA, I: systematics and ecology. - Great Basin Naturalist 58: 97-146.

Stevens, L.E., Sublette, J.E. and Shannon, J.P. 1998. Chironomidae (Diptera) of the Colorado River, Grand Canyon, Arizona, USA, II: factors influencing distribution. - Great Basin Naturalist 58: 147-155.

Butler, M.G., Kiknadze, I.I., Golygina, V.V., Martin, J., Istomina, A.G., Wülker, W.F., Sublette, J.E., Sublette, M.F. (1999) Cytogenetic divergence between Palearctic and Nearctic populations of Chironomus plumosus L. (Diptera, Chironomidae). Genome, 42, 797-815.

Butler, M.G., Kiknadze, I.I, Golygina, V.V., Istomina, A.G., Wülker, W.F., Martin, J., Sublette, J.E. and Sublette, M.F. 2000. Macrogeographic patterns of banding sequences in Holarctic Chironomus plumosus L. In: Hoffrichter, O. (Ed.) Late 20th Century Research on Chironomidae: an Anthology from the 13th International Symposium on Chironomidae. Shaker Verlag, Aachen, pp. 51-57.

Kiknadze, I.I., Butler, M.G., Golygina, V.V., Martin, J., Wülker, W.F., Sublette J.E. and Sublette M.F. 2000. Intercontinental karyotypic differentiation of Chironomus entis Shobanov, a Holarctic member of the C. plumosus group (Diptera, Chironomidae). - Genome 43: 857873.

Kiknadze, I.I., Butler, M.G., Golygina, V.V., Wülker, W.F., Martin, J., Sublette, J.E. and Sublette, M.F. 2000. Macrogeographic patterns of banding sequences in Holarctic Chironomus entis Shobanov. In: Hoffrichter, O. (Ed.) Late 20th Century Research on Chironomidae: an Anthology from the 13th International Symposium on Chironomidae. Shaker Verlag, Aachen, pp. 135-141. 
Ruse, L.P., Herrmann, S.J. and Sublette, J.E. 2000. Chironomidae (Diptera) species distribution related to environmental characteristics of the metal-polluted Arkansas River, Colorado. Western North American Naturalist 60: 34-56.

Sublette, J.E. and Mulla, M.S. 2000. Chironomus strenzkei Fittkau - a new Pan-American distribution, with a review of recent similar additions to the Nearctic midges. - Spixiana 23: 145-149.

Spies, M., Sublette, J.E., Sublette, M.F., Wülker, W.F., Martin, J., Hille, A., Miller, M.A. and Witt, K. 2002. Pan-American Chironomus calligraphus Goeldi, 1905 (Diptera, Chironomidae): species or complex? Evidence from external morphology, karyology and DNA sequencing. - Aquatic Insects 24: 91-113.

Ekrem, T., Sublette, M.F. and Sublette, J.E. 2003. North American Tanytarsus I. Descriptions and keys to species in the eminulus, gregarius, lugens and mendax species groups (Diptera: Chironomidae). - Annals of the Entomological Society of America 96: 265-328.

Fittkau, E.J., Frommer, S.I. and Sublette, J.E. 2008. Jehoshua Kugler 1. February 1916 - 24. October 2007. - Chironomus Newsletter on Chironomidae Research 21: 7-9.

Hribar, L.J., Epler, J.H., Martin, J. and Sublette, J.E. 2008. Chironomus columbiensis (Diptera: Chironomidae) new to the fauna of the United States. - Florida Entomologist 91: 470-471.
Wülker, W.F., Martin, J., Kiknadze. I.I., Sublette, J.E. and Michiels, S. 2009. Chironomus blaylocki sp. n. and C. bifurcatus sp. n., North American species near the base of the decorus-group (Diptera: Chironomidae). - Zootaxa 2023: 28-46.

Bolton, M.J., Ekrem, T., Sublette, J.E. and Sublette, M.F. 2010. A new species of Paratanytarsus Thienemann and Bause (Diptera: Chironomidae) with unusual larval and adult male morphology. In: Ferrington, L.C. Jr. (Ed.), Proceedings of the XV International Symposium on Chironomidae, Chironomidae Research Group, University of Minnesota, St. Paul, pp. 262-271.

Martin, J., Sublette, J.E. and Caldwell, B.A. 2010. Description of Chironomus quinnitukqut, $\mathrm{n}$. sp., closely related to the $C$. decorus group in North America, with characterization of an additional larval form from halobiontic habitats. - Zootaxa 2716: 29-41 \& 2743: 68.

Añón Suárez, D.A. and Sublette, J.E. 2012. Wuelkerella toncekensis n. gen., n. sp. (Diptera: Chironomidae: Tanypodinae) from Argentina. - Zootaxa 3177: 59-65. 